\title{
Index of Mangrove Health Around the Ex-Bauxite Mining Area, Tanjungpinang City, Riau Islands Province
}

\author{
Diana Azizah ${ }^{1 *}$, Rasoel Hamidy ${ }^{2}$, Mubarak Mubarak $^{2}$, Efriyeldi Efriyeldi ${ }^{3}$, Wahyu Muzammil ${ }^{1}$, \\ Febrianti Lestari ${ }^{1}$, Sri Murtini ${ }^{4}$ \\ ${ }^{1}$ Aquatic Resources Management Department, Faculty of Marine and Fisheries Sciences, Raja Ali Haji Maritime University, \\ Tanjungpinang, Riau Islands, 19100, Indonesia \\ ${ }^{2}$ Environmental Science Doctoral Program, Riau University, Pekanbaru, Riau, 19200, Indonesia \\ ${ }^{3}$ Marine Science Departement, Faculty of Fisheries and Marine Science, Riau University, Pekanbaru, Riau, 19200, Indonesia \\ ${ }^{4}$ Fisheries Departement, Faculty of Agriculture, Bina Insan University, South Sumatra, 19500, Indonesia
}

\begin{abstract}
There are several former bauxite mining areas on Bintan Island which until now have been left open and not managed properly. In Tanjungpinang, the location of the former bauxite mine is located around the mangrove forest ecosystem. The impact of bauxite mining that changes the structure, texture, and physical of the soil can interfere with the development of the root system and the growth of surrounding plants, including mangroves. Therefore, it is necessary to know the health condition of mangroves around the former bauxite mining area. The method used is a cluster plot by calculating the percentage of tree damage based on organ location, type, and level of damage. The results of the analysis show that the health condition of the mangrove forest in Tanjungpinang City is healthy $(50,9 \%)$; slightly damaged $(40,4 \%)$ and moderately damaged $(8,8 \%)$. The locations of the organs that suffered the most damage were roots, lower and upper stems, and leaves. The most common type of damage found roots submerged in red mud; stems and leaves covered with dust and red sand; termite; broken stem; roots break and die; broken shoots; and the leaves change color. The greatest severity is found between $10 \%$ and $20 \%$.
\end{abstract}

\section{Introduction}

Bintan Island in the Riau Archipelago has a high potential for bauxite metal. So that bauxite mining activities are rampantly carried out on a large scale, both legally and illegally. In recent years, bauxite resources as a strategic commodity in mining areas in Bintan are estimated to be nearing exhaustion. However, with a tendency to increase prices and the need for bauxite which affects the economic value of the existing resource potential, it is possible that low-grade bauxite that was not utilized may become potential for cultivation. Bauxite mining activities on Bintan Island generally have not applied the concept of good mining management (good mining practice) during operation to post-mining.

Although some bauxite mining activities on Bintan Island have stopped, the remaining environmental damage from these activities is still visible in several areas, especially mangrove areas in the coastal areas of Bintan Island[1-3]. There has been no effort to restore (restoration) the damage to the mangrove forest around the mine site. This condition persisted for years. The impact of which is the rate of increase in critical areas of mangrove forests will increase because the bauxite mining business is economically profitable. Meanwhile, the cost of repairing environmental damage (rehabilitation) of mangrove forests after bauxite mining is very large.

Mangrove forests on Bintan Island are included in the coastal resources that can be restored [4]. Meanwhile, the potential for bauxite is a resource that is difficult to recover [5]. The benefits of bauxite mining activities are only temporary. The Meanwhile, environmental damage due to land clearing and mining activities tends to have a longer impact [6]. The level of diversity is often used as an object in mangrove forest management, but besides that, the health condition of mangrove trees needs to be an indicator in determining mangrove management efforts. Because the level of forest health shows how the mangrove trees adapt to changes in the quality of their environment. Many studies of mangrove biodiversity in Tanjungpinang City have been carried out, but the health condition of the mangroves around the former bauxite mining area has not been carried out. Therefore, this study is expected to be able to describe the health condition of the mangroves found around the former bauxite mining areas in Tanjungpinang City.

\footnotetext{
* Corresponding author: diana_azizah@umrah.ac.id
} 


\section{Materials and Method}

Observations on the health of mangrove trees were carried out based on the condition of the damaged trees. Tree damage data was collected using observation plots (cluster plots/cluster plots) based on the Forest Health Monitoring method [7]. The FHM plot cluster used in this study consists of 4 (four) plots (Fig. 1) located in Carang River and Senggarang respectively.

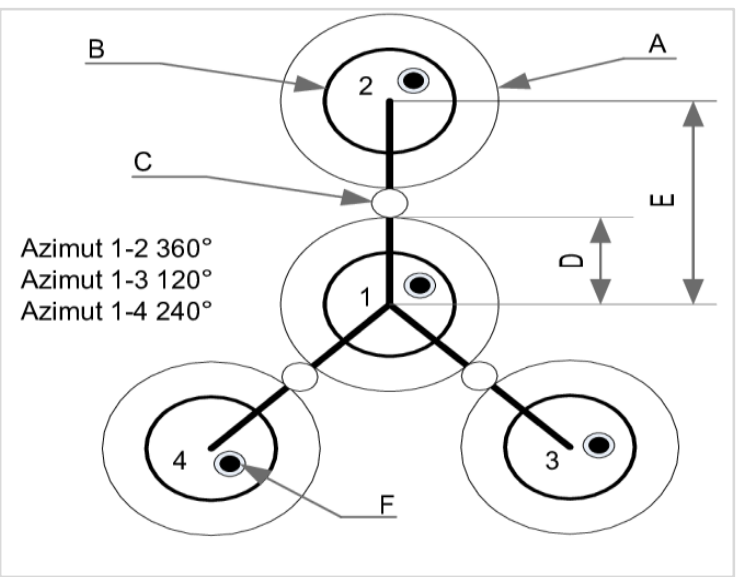

Figure 1. FHM cluster-plot design (Mangold, 1997). Note: A $=$ Annular plot radius $17.95 \mathrm{~m} ; \mathrm{B}=7.32 \mathrm{~m}$ radius subplot $\mathrm{C}=$ soil sample point; $\mathrm{D}=$ the distance of the soil sample point from the center of the subplot is $18 \mathrm{~m}$; $\mathrm{E}=$ distance between plot centers is $36.6 \mathrm{~m}$; $\mathrm{F}=$ micro plot radius $2.07 \mathrm{~m}$ per azimuth and distance from the center point of the subplot is $3.66 \mathrm{~m}$.

The tree damage parameters used consisted of the location of the damage to the tree (part of the organ), the type of damage, and the severity (\%). The locations of tree damage recorded were at roots, stems, branches, crowns, leaves, shoots, and shoots. The type of tree damage was assessed based on the threshold level of severity of damage that could kill the tree or affect the long-term viability of the tree [8]. A maximum of only three of the most severe damage was recorded. Observation codes and weights used to make it easier to analyze tree damage can be seen in Table 1 . The next step is to calculate the condition of tree damage by multiplying the weights ( $\mathrm{x}, \mathrm{y}$, and $\mathrm{z}$ ) to determine the damage index. The results of the final calculation can be seen in the health category of mangrove trees. The formula used is:

$$
\mathbf{N I K}=\sum_{i=1}^{n}(\boldsymbol{x} i, \boldsymbol{y} i, \boldsymbol{z} i)
$$

Information :

NIK = Damage Index Value at Tree Level

$\mathrm{xi}=$ value on the part/location of the damaged tree

$\mathrm{yi}=$ value on the type of damage

$\mathrm{zi}=$ value on severity

Tree damage class refers to the weighted index value with the following criteria: Healthy class $=0$ to $<5$; Light damage class $=6$ to 10 ; Medium damage class $=$ 11 to 15 ; Heavy damage class $=16$ to $>21$.

\section{Result and Discuss}

The observed mangrove health included tree strata which were sampled using cluster plots at each research location. Observations of trees were carried out starting from the roots to the top (shoots/leaves) which included location groups (organs), type, and percentage of the severity of damage [9]. The results of observations and analysis of mangrove health data around the former bauxite mining area of Tanjungpinang City are presented in Tables 2 and 3.

Table 1. Code, location, type, severity and weight calculation of mangrove tree damage (Safe'i et al., 2019)

\begin{tabular}{|c|l|c|c|l|c|c|c|c|}
\hline Code & Location of damage & $\begin{array}{c}\text { value } \\
(\mathbf{x})\end{array}$ & Code & Type of damage & $\begin{array}{c}\text { value } \\
(\mathbf{y})\end{array}$ & $\begin{array}{c}\text { Level of } \\
\text { Code } \\
(\mathbf{\%})\end{array}$ & $\begin{array}{c}\text { value } \\
(\mathbf{z})\end{array}$ \\
\hline 0 & Healthy (no damage) & 0,0 & 1 & Cancer & 1,9 & 0 & 0 & 1,5 \\
\hline 1 & Roots & 2,0 & 2 & Konk & 1,7 & 1 & 10 & 1,1 \\
\hline 2 & $\begin{array}{l}\text { roots \& bottom of } \\
\text { stems }\end{array}$ & 2,0 & 3 & Open wound & 1,5 & 2 & 20 & 1,2 \\
\hline 3 & Bottom of stems & 1,8 & 4 & Resinosis & 1,5 & 3 & 30 & 1,3 \\
\hline 4 & $\begin{array}{l}\text { Bottom of stems \& } \\
\text { upper }\end{array}$ & 1,8 & 5 & Broken stem & 2,0 & 4 & 40 & 1,4 \\
\hline 5 & Upper stems & 1,6 & 6 & Termite nest & 1,5 & 5 & 50 & 1,5 \\
\hline 6 & Stem section header & 1,2 & 11 & Broken stems/roots & 2,0 & 6 & 60 & 1,6 \\
\hline 7 & Branch & 1,0 & 12 & Brum on rootstem & 1,6 & 7 & 70 & 1,7 \\
\hline 8 & Buds & 1,0 & 13 & Broken/dead roots & 1,5 & 8 & 80 & 1,8 \\
\hline 9 & Leafs & 1,0 & 20 & Liana & 1,5 & 9 & 90 & 1,9 \\
\hline & & & 21 & Dead of buds & 1,3 & & & \\
\hline & & & 22 & Broken/dead branch & 1,3 & & & \\
\hline & & & 23 & Brum & 1,3 & & & \\
\hline & & & 24 & Damaged leaves, buds & 1,3 & & & \\
\hline & & & 26 & Leaves changing color & 1,0 & & & \\
\hline & & & 31 & Ouru rust & 1,9 & & & \\
\hline & & & & 1,0 & & & \\
\hline
\end{tabular}

Table 2. Percentage of Damage to Mangrove Trees Around the Former Bauxite Mine Area of Tanjungpinang City, Indonesia

\begin{tabular}{|c|c|c|c|}
\hline Location & $\begin{array}{c}\text { Number of } \\
\text { Trees } \\
\text { sample }\end{array}$ & $\begin{array}{c}\text { Number } \\
\text { of damage } \\
\text { trees }\end{array}$ & $\begin{array}{c}\% \\
\text { damage }\end{array}$ \\
\hline Carang Rivers & 27 & 13 & 23,2 \\
\hline Senggarang & 29 & 15 & 26,8 \\
\hline Total & 56 & & 50,0 \\
\hline
\end{tabular}

Table 3. Mangrove Health Levels Around the Former Bauxite Mine Area of Tanjungpinang City, Indonesia

\begin{tabular}{|c|c|c|c|c|}
\hline \multirow{2}{*}{$\begin{array}{c}\text { Level of } \\
\text { damage } \\
\text { of trees }\end{array}$} & \multicolumn{2}{|c|}{ Number of case } & \multirow{2}{*}{ Amount } & \multirow{2}{*}{$\begin{array}{c}\text { Percentag } \\
\text { e }(\%)\end{array}$} \\
\hline & $\begin{array}{l}\text { Carang } \\
\text { River }\end{array}$ & Senggarang & & \\
\hline Healthy & 14 & 15 & 29 & 50,9 \\
\hline Lightly & 11 & 12 & 23 & 40,4 \\
\hline Currently & 2 & 3 & 5 & 8,8 \\
\hline Heavy & 0 & 0 & 0 & 0,0 \\
\hline \multicolumn{3}{|c|}{ Total } & 57 & 100 \\
\hline
\end{tabular}

Based on the table above, it is known that of the 56 mangrove trees found around the former bauxite mining area, $26,8 \%$ of the trees are classified as damaged. Although the condition of the mangrove trees was mostly healthy $(23,2 \%)$, there were also cases of trees that suffered light to moderate damage. The percentage of cases of damage to mangrove trees is presented in Table 4. 
The damage that occurs predominantly occurs in the organs of roots, stems and leaves. Based on the type of damage, the types of damage found included damaged leaves, discolored leaves, termites, dead roots and broken leaves, resinosis in the form of gumosis, broken branches, and open wounds. While the other categories found as much as $30 \%$ in the form of roots covered with red mud (red-mud), some even reached the lower stems, and leaves covered with dust from dried red mud. This is thought to cause several other damage problems such as damaged roots and stems (changed color, rotted and not functioning) as well as fallen and wilted leaves (Fig. 2 ). Open wound conditions were found in $2 \%$ of Rhizophora mucronata stems in Senggarang. The wound was probably caused by a cut on the stem of Rhizophora mucronata caused by sharp objects from the residents around the location.

Resinosis/gummosis conditions were found in $2 \%$ of the branches of Rhizophora apiculata and the lower trunk of Bruguiera gymnorhiza. Gummosis is a dark brown viscous liquid that comes out of the injured tree organ (hollow). The observed termite nests were found as much as $10 \%$. Termites cause tree trunks to peel and small holes in large numbers. According to Haikal et al., (2020) the presence of termites on the stem is characterized by the discovery of soil crust that covers the stem and can cause plant death.

Termite attacks do not only occur on one tree but can spread to other trees through trunks, branches, twigs on the forest floor or from lianas on the tree. Types of broken stem damage (1\%), broken $(9 \%)$, broken/dead roots $(9 \%)$ and broken/dead branches (2\%) were found in Avicennia alba, Avicennia marina, Rhizophora apiculata, Rhizophora mucronata, Sonneratia alba, Ceriops tagal and Xylocarpus granatum. The damage it causes is the loss of the tip or base of the twigs and leaves and then occurs in weathering of dead branches.

The cause is thought to be due to the activities of local residents entering the mangrove forest area, winds that are too strong, or weathering. In addition, the condition of damaged leaves was found as much as $20 \%$ and leaves that changed color as much as $14 \%$. Symptoms that can be seen are leaf chlorosis (lack of green matter) such as turning yellow or brown, brown or black spots, and withered leaves [5]. stated that the symptoms of leaf damage can be caused by the absence of chlorophyll formation due to the presence of pathogens, toxins, excess chemicals, or burning by temperatures that are too high.
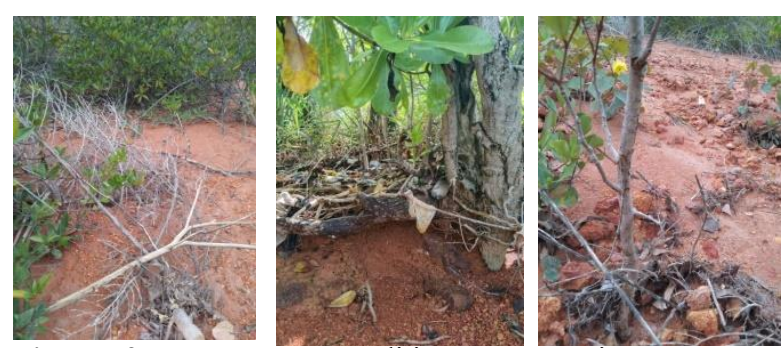

Figure 2. Mangroves condition at Sungai Carang and Sengarang which left picture is broken of stems; the middle picture is the change of leaves color and the right picture is the dead of roots.
Table 4. Percentage of Cases Found Based on Location, Type and Level of Damage to Mangrove Trees Around the Former Bauxite Mine Area of Tanjungpinang City

\begin{tabular}{|c|c|c|c|c|c|c|c|c|}
\hline Code & $\begin{array}{l}\text { Location } \\
\text { of } \\
\text { damage }\end{array}$ & $\begin{array}{l}\text { Number } \\
\text { of case } \\
(\%)\end{array}$ & Code & $\begin{array}{l}\text { Type of } \\
\text { damage }\end{array}$ & $\begin{array}{l}\text { Number } \\
\text { of case } \\
(\%)\end{array}$ & Code & $\begin{array}{l}\text { Level of } \\
\text { severity } \\
(\%)\end{array}$ & $\begin{array}{l}\text { Number } \\
\text { of case } \\
(\%)\end{array}$ \\
\hline 0 & $\begin{array}{l}\text { Healthy } \\
\text { (no } \\
\text { damage) }\end{array}$ & 17 & 1 & Cancer & 0 & 0 & $0 \%$ & 17 \\
\hline 1 & Roots & 23 & 2 & Konk & 0 & 1 & $10 \%$ & 16 \\
\hline 2 & $\begin{array}{l}\text { Roots \& } \\
\text { bottom } \\
\text { of stems }\end{array}$ & 19 & 3 & $\begin{array}{l}\text { Open } \\
\text { wound }\end{array}$ & 2 & 2 & $20 \%$ & 34 \\
\hline 3 & $\begin{array}{l}\text { Bottom } \\
\text { of stems }\end{array}$ & 5 & 4 & Resinosis & 2 & 3 & $30 \%$ & 4 \\
\hline 4 & $\begin{array}{l}\text { Bottom } \\
\text { of stems } \\
\& \text { upper }\end{array}$ & 5 & 5 & Broken stem & 1 & 4 & $40 \%$ & 0 \\
\hline 5 & $\begin{array}{l}\text { Upper } \\
\text { stems }\end{array}$ & 0 & 6 & Termite nest & 10 & 5 & $50 \%$ & 12 \\
\hline 6 & $\begin{array}{l}\text { Stem } \\
\text { section } \\
\text { header }\end{array}$ & 1 & 11 & $\begin{array}{l}\text { Broken } \\
\text { stems/roots }\end{array}$ & 9 & 6 & $60 \%$ & 0 \\
\hline 7 & Branch & 2 & 12 & $\begin{array}{l}\text { Brum on } \\
\text { root/stem }\end{array}$ & 0 & 7 & $70 \%$ & 3 \\
\hline 8 & Buds & 0 & 13 & $\begin{array}{l}\text { Broken/dead } \\
\text { roots }\end{array}$ & 9 & 8 & $80 \%$ & 0 \\
\hline \multirow[t]{8}{*}{9} & Leafs & 29 & 20 & Liana & 0 & 9 & $90 \%$ & 15 \\
\hline & & & 21 & $\begin{array}{l}\text { Dead of } \\
\text { buds }\end{array}$ & 0 & & & \\
\hline & & & 22 & $\begin{array}{l}\text { Broken/dead } \\
\text { branch }\end{array}$ & 2 & & & \\
\hline & & & 23 & Brum & 0 & & & \\
\hline & & & 24 & $\begin{array}{l}\text { Damaged } \\
\text { leaves, buds }\end{array}$ & 20 & & & \\
\hline & & & 25 & $\begin{array}{l}\text { Leaves } \\
\text { changing } \\
\text { color }\end{array}$ & 14 & & & \\
\hline & & & 26 & Puru rust & 0 & & & \\
\hline & & & 31 & Others & 30 & & & \\
\hline
\end{tabular}

Severity is the percentage of the type of damage encountered in a tree. The severity level with a threshold value of $90 \%$ found 28 cases, most of which occurred in the Carang River. A severity of $70 \%$ only occurred in 6 cases in Senggarang. The severity level of 50\% was also found in 28 cases, most of which occurred in Senggarang. While the severity of $20 \%$ is the largest, namely 68 cases, most are found in Senggarang

\section{Conclusion}

Index of mangrove healthy in former of ex-bauxite mining area in Tanjungpinang City is in healthy level, even though lightly condition was found. The percentage of location that was damaged is found at roots, stems, and leaves. Impact of bauxite area is make died about roots and stems and also damage of leaves.

\section{Reference}

1. A. P. Nieto, C. Soriano, M. Llorente, I. Palomo, C. Montes, and B. López, Ecosystem Services 13, 141 (2015).

2. T. R. Grigalunas and C. Congar, Environmental Economics for Integrated Coastal Area Management (1995).

3. Y. Yudithia, E. Edison, D. Kristanti, T. Samnuzulsari, S. Suyito, and W. E. Yudiatmaja, E3S Web of Conferences 202, 09001 (2020).

4. R. F. Oktaviana, A. S. Muhammad, F. Kurnianingsih, and M. Mahadiansar, Indonesian Journal of Tourism and Leisure 2, 51 (2021). 
5. D. Akbar, I. Irman, W. E. Yudiatmaja, and K. Fadli, IOP Conference Series: Earth and Environmental Science 724, 012103 (2021).

6. R. Wurzel, A. R. Zito, and A. Jordan, Environmental Governance in Europe: A Comparative Ananlysis of New Environmental Policy Instruments (Edward Elgar Publishing, Cheltenham, 2013).

7. O. Barbosa and C. Alves, in CEUR Workshop Proceedings (2011).

8. R. Mangold, Forest Health Monitoring: Field Methods Guide (USDA Forest Service, 1997).

9. A. Rizal, Biodiversity International Journal 2, (2018). 